\title{
Chinese Diasporic Culture and National Identity: The Taming of the Tiger Balm Gardens in Singapore
}

\author{
JIANLI HUANG and LYSA HONG
}

\author{
National University of Singapore
}

\begin{abstract}
The Tiger Balm Gardens or Haw Par Villa, built in the 193 os by overseas Chinese pharmaceuticals tycoon Aw Boon Haw, has been and remains a symbol of the positioning of Singapore's Chineseness. In the colonial era, it marked the success not only of one man but also of the Chinese migrant community. In the later period of nation-building, it was initially considered as a challenge to multiracialism and nationhood. However, as state policy shifted towards an ethnicized cultural identity as prompted by the rise of Asia as a major economic force, especially China, the Villa was renovated first into an orientalized theme park and then resuscitated as the repository of diasporic Chinese entrepreneurship. Amidst these state initiatives, the history of the Villa and its founder were sidelined.
\end{abstract}

\section{From colony to nation-state: The importance of being 'Chinese'}

Aw Boon Haw (1882-1954), the owner of the Tiger Balm Gardens, was a legendary figure even among the wealthiest and most influential of overseas Chinese business and pan-community leaders of the colonial era in Southeast Asia. He fashioned a pair of theme gardens in the 193 os on the extensive grounds of his private residence in Hong Kong and that of his brother Boon Par in Singapore, which they opened to the public. More concrete and paint than landscaped greenery

Jianli Huang is Associate Professor of History at the National University of Singapore. His e-mail contact is hishjl@nus.edu.sg. Lysa Hong is Visiting Senior Fellow at the History Department, National University of Singapore and her e-mail address is hishl@nus.edu.sg.We wish to thank Wong Poh Poh, Leander Seah and Edna Tan for their assistance to our research. An earlier version of this article, 'Reflections on Chinese Diasporic Culture: The Tiger Balm Gardens in Singapore and Hong Kong' by Huang Jianli, was presented at the HKU-NUS Joint Workshop on Hong Kong and Singapore in History: A Comparative Study, Hong Kong, 4-5 December 2003.

0026-749X/o7/\$7.5 $\mathrm{O}+\$ 0.10$ 
that the word 'gardens' (huayuan) would normally evoke, the twin Gardens, also named Haw Par Villa after their owners, ${ }^{1}$ were Aw's projection of his personality and public position as a leading overseas Chinese tycoon. Much as his fabled Tiger Balm 'cure-all' ointment has become an international brand name, his signature public-access grounds stamped Aw Boon Haw's presence in the minds of both the local visitors and tourists who visited these popular sightseeing spots. For half a century, the family fortune allowed for the maintenance of the Villas. If not in terms of anything else, such care bestowed on them the rarity of being the pristine relic of a long-gone era, while the landscape of the two premier British trading port centres in Asia were drastically urbanized into land-scarce, high-rise, commercial, industrial and financial hubs.

Regardless of how much historical value they had come to bear from their sheer resilience in the face of time and spatial pressures, however, the Villas could not outlive the wealth of the Aw family. In 1971 a substantial part of the Hong Kong complex, standing on prime land with a coveted view of Victoria Harbour, was sold to property developers who put up condominium blocks on the site; the rest of the Villa met a similar fate in December 1998 to stave off bankruptcy suits against Sally Aw Sian, who had inherited the Hong Kong branch of the family empire. ${ }^{2}$ However, the legacy of the Hong Kong Villa was not entirely obliterated. Its iconic cement-and-paint statues and tableaux depicting the horrible retributions for evildoers prescribed in Chinese folk culture, as well as stories of heroism and virtue, were rescued by the drug rehabilitation centre on Shek Kwu Chau island, which saw their potential as an 'anti-drug garden museum', attracting tourists who would want to see different facets of Chinese culture and heritage, as well as local visitors in need of anti-addiction messages. ${ }^{3}$

The last decades of the millennium were no less traumatic for the Singapore Tiger Balm Gardens. The Singapore branch of the Aw family similarly witnessed the serious erosion of its business empire and was thus reluctant to continue footing the bill for the

${ }^{1}$ Both the names 'Tiger Balm Gardens' and 'Haw (tiger) Par (leopard) Villa' (in English and Chinese) appear at the entrance of the Gardens. They are used interchangeably in this study. Aw Boon Haw intended to build a third Villa during 1948 in his native village of Yongding, China. However, the communist victory of 1949 led to his assets and properties being seized by the new regime.

2 Asiaweek, 12 Dec. 1999; South China Morning Post, 24 Mar. 1999, 24 Sep. 20oo; Hong Kong Standard, 29 Oct. 2000.

${ }^{3}$ South China Morning Post, 24 Sep. 2000; Hong Kong Standard, 29 Oct. 2000. 
upkeep of the grounds. The property was acquired by the state in 1985. For the Singapore authorities, specifically the Singapore Tourist Promotion Board, ${ }^{4}$ taking over as the owners of an overseas Chinese tycoon's playground required a re-positioning of the site in terms of the nation-state's marketing of itself in the highly competitive arena of tourism. The Board's packaging of Haw Par Villa as a hightechnology Chinese mythological theme park with Disneyland as its reference point was spectacular in both its ambition and the eventual financial losses incurred by its operators. The Villa has thus become the subject of academic critiques within the framework of tourism and the globalization-localization tensions in the age of flexible capital accumulation. ${ }^{5}$ Following the decisive rejection of the theme park by market forces, the Tourism Board changed its tack, and it has resorted to the rhetoric of returning the Villa to its original mien. However, a directive on how the 193os-era Villa is to remain connected with the contemporary nation state has been appended to this restorative effort in the form of an overseas Chinese museum located on its grounds.

The imperatives of selling Singapore as a tourist destination is thus inextricably tied to how the country would like to be understood by both its citizens and outsiders. National identity is part of the package that tourists are meant to imbibe as the 'Singapore experience'. This 'experience' has increasingly come to be postulated as being larger than the geographical boundaries demarcating 'Singapore'. At the globalized turn of the millennium, the transnationalism of the overseas Chinese which Aw Boon Haw and his business empire epitomised during the era of colonial Southeast Asia has been harnessed to enlarge discursively this spatially-challenged island citystate. The extra-territorial narratives of the Chinese diaspora have been codified in the appended overseas Chinese museum in the Villa, with Singapore as the host, patron and living exemplar of this

4 The Singapore Tourist Promotion Board was renamed the Singapore Tourism Board in 1997 to reflect its enlarged corporate objectives, from destination marketing to promoting the business of tourism. T. C. Chang and Peggy Teo, 'From rhetoric to reality: Cultural heritage and tourism in Singapore', in Singapore Inc.: Public policy options in the third millennium, eds. Linda Low and Douglas M Johnston (Singapore: Eastern University Press, 2003), p. 302.

${ }^{5}$ Brenda S. A. Yeoh and Peggy Teo, 'From Tiger Balm Gardens to Dragon World: Philosophy and profit in the making of Singapore's first cultural theme park', Geografiska Annaler Series B, Human Geography, 78.1 (1996): 27-42; Peggy Teo and Brenda S. A. Yeoh, 'Remaking local heritage for tourism', Annals of Tourism Research, 24:1 (1997): 192-2 13; Peggy Teo and Lim Hiong Li, 'Global and local: Interactions in tourism', Annals of Tourism Research, 30.2 (2003): 287-306. 
shrine and magnet of diasporic entrepreneurialism. The trajectories that Haw Par Villa has taken as a state-sponsored tourist attraction have therefore been propelled by the tensions between ethnicity and nationhood, specifically the positions and meanings of Chineseness as endorsed by the state in relation to 'China', the mythical source.

The transformations which the Villa has undergone thus offer an entry point into exploring various aspects of the last half century of Singapore's history, from colony to nation-state. The project of producing a distinctive national identity out of the racial streams that comprise Singapore's predominantly migrant population-Chinese (76.8 percent), Malay (13.9 percent), Indian (7.9 percent), Eurasian and others $(1.4 \text { percent })^{6}$-has employed 'multiracialism' as its keyword ever since the road to independence in the $195^{\circ}$ s. By the late 1970s, the economic viability of the country was more or less assured by the successful wooing of foreign investment, modern infrastructure, and a relatively well-educated, disciplined and competitively priced work force. Even so, the state has argued against a corresponding political openness on the grounds that racial sensitivities are potentially incendiary, and the strong and even hand of the state has been needed to maintain 'stability'-another keyword in Singapore's political lexicon.

Such defensive rhetoric was supplemented with a more aggressive stance when Singapore emerged as one of the leading 'Asian capitalism' dynamos of the 1980 os and 1990s. It became a 'prime site for the contemporary re-articulation of the Orientalist masternarrative of West versus East, where an empowered East, having appropriated and reconstituted Western modernity, now unsettles the established hegemony of the West by questioning its moral worth'. ${ }^{7}$ Fundamentally, with its official history locating its origins as a colonial entrepôt, Singapore has been 'always-already Westernised'. Nonetheless, the master-binary of East and West and the racial essentialism of the British Empire were subsequently transformed by the post-colonial nation-state to signify the creative communitarianism and morality of the East against the destructive individualism and decadence of the West. The official Singapore discourse on

\footnotetext{
${ }^{6}$ Population census for Year 2000, Singapore Department of Statistics, www.singstat.gov.sg.

${ }^{7}$ Ien Ang and Jon Stratton, 'The Singapore way of multiculturalism: Western concepts/Asian cultures', Sojourn, 10.1 (Apr. 1995): 66.

${ }^{8}$ Ibid., p. 67.
} 
self-representation thus relies on the strategies of Occidentalism and self-Orientalization. ${ }^{9}$

However, 'Asia' is neither homogenous nor are its component races equal according to this self-representation. Indeed, while the state has embarked on a large-scale programme of 'inventing nativity' by celebrating the native origins of the different ethnic groups which have constituted its population, ${ }^{10}$ it has clearly been 'Chinese culture' that was privileged. Be it on the grounds of Singapore's demography, the postulation of Confucianist modernity as the explanation for the East Asian Economic Miracle, or the seemingly unlimited economic opportunities promised by an increasingly open China market, Malay and Indian Singaporeans just would not have been able to find their cultures given a similar amount of social space as the Chinese. From their point of view, the emphasis given to learning Mandarin, defined as the mother tongue of the Chinese, has been no less if not actually more than that given to the English language. ${ }^{11}$

In valorizing Asian/Chinese values so positively, the authorities had to reassess the place in national history of the larger-than-life Chinese tycoons whose very successes had been wrought by interests and networks that were distinctly diasporic, and to whom the colonial settlement of Singapore was a base of operations rather than a locus of loyalty. Earlier on, the fissures which they had represented (such as family, clan, dialect and ethnic identities spanning political boundaries) had invalidated a place for them in the early history texts mapping the genealogy of independent Singapore. In fact, the Chinese business leaders had been much derided by the then socialist Englisheducated People's Action Party (PAP) under Lee Kuan Yew during the

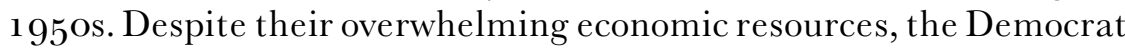
Party formed by Chinese businessmen to contest the 1955 Legislative Assembly elections had lost badly, with the PAP attacking them as 'capitalists and exploiters of the people' ${ }^{12}$ Lee had projected them as being un-national in their interests:

[They] were Chinese who made a good living as importers and exporters, retailers, merchants and shopkeepers, bankers and rubber or tin magnates.

${ }^{9}$ Ibid., p. 69.

${ }^{10}$ Ibid., p. 75 .

${ }^{11}$ Nirmala Puru Shotam, Negotiating multiculturalism: Disciplining difference in Singapore (Berlin: Mouton de Gruyter, 2000), pp. $210-14$.

${ }^{12}$ Lee Kuan Yew, The Singapore Story: Memoirs of Lee Kuan Yew (Singapore: Times Editions, 1998), p. 191. 
They were the leaders of the Chinese-speaking traditional guilds; they were in charge of the Chinese schools, which they paid for and ran through their boards of management; and they funded and administered charitable Chinese clan hospitals and other welfare organisations. They saw this election as their chance to get at the levers of power that would increase their business prospects. ${ }^{13}$

Despite being pan-Chinese household names in their days, men like Tan Kah Kee (1874-1961), Aw Boon Haw (1882-1954) and Tan Lark Sye (1897-1972) initially had no place in the official Singapore memory. With the Asian values discourse, however, a gradual rehabilitation of these entrepreneurs extraordinaires could be discerned. ${ }^{14}$ The reformulation of Haw Par Villa from the mid1980 s therefore marked a refinement to the meaning and import of being Chinese as defined by the state. The numerous stumbles along the way indicate just how awkward that exercise has been.

\section{The villa that Aw built: The tiger and his habitat}

Tiger Aw was one of three sons of the yellow emperor singled out in Lynn Pan's story of the overseas Chinese as the epitome of a particular kind of community leadership. While Loke Wan Tho (19151964), the Cambridge-educated son of a Kuala Lumpur tin magnate, was deemed to be of 'scholarly bent and gentle manner' as well as 'the product of a gentleman's culture' and the 'very antithesis of the archetypal philistine and opportunistic immigrant Chinese', ${ }^{15}$ Tan Kah Kee and Aw Boon Haw both typified the spectacular rags-toriches success story that was the dream of the Chinese sojourner. Nevertheless, Tan and Aw also stood in contrast to each other. The former was the undisputed leader of the majority Hokkien dialect group. He dominated the Chinese Chamber of Commerce and the South Seas China Relief Fund Union, set up in 1938 to organize fund raising campaigns among the estimated eight million overseas Chinese in support of China in the face of Japanese aggression, and

${ }^{13}$ Ibid., p.19o.

${ }^{14}$ Hong Lysa and Huang Jianli, 'The scripting of Singapore's national heroes: Toying with Pandora's box', in New terrains in Southeast Asian history, eds. Abu Talib Ahmad and Tan Liok Ee (Athens, Ohio: Ohio University Press and Singapore University Press), pp. 219-46.

${ }^{15}$ Lynn Pan, Sons of the yellow emperor: The story of the overseas Chinese (London: Secker \& Warburg, 1990), p. 189. 
lived out his last years in communist China. This 'Henry Ford of Malaya' was sober in taste and Spartan of habit, and his own selfdenial was unremitting. ${ }^{16}$ He was also disdainful of Aw Boon Haw, even though the latter was at least Tan's equal when it came to massive donations made to schools, hospitals, temples and charity institutions.

Of the three men, Aw Boon Haw comes closest to Pan's caricature of the overseas Chinese as opportunistic and philistine, as well as to Lee Kuan Yew's condemnation of them as parochial and purely profit-oriented. He was born in Yangon, Burma into the family of a Hakka migrant from Yongding county, Fujian province, who had married a local-born Chinese wife. After their father's death in 1908, Aw Boon Haw and his brother Boon Par built a regional business empire producing and marketing pharmaceutical products, starting out with their concoction: the Tiger Balm ointment. ${ }^{17}$ Aw moved his base to Singapore in the mid-1920s, and subsequently also established himself in Hong Kong and China, where his interests were partly protected by his membership in the Green Gang secret society. ${ }^{18}$ His business expanded to include newspaper publishing, insurance and banking. Aw Boon Haw was flamboyant and publicityseeking to a fault, never passing up an opportunity to advertise and market his products. Coming from a minority dialect group, he had great difficulty establishing a role for himself as a Chinese leader in Singapore where the colonial authorities left the self-help organisations, in particular clan and dialect associations, to fend for the welfare of their constituents. The majority Hokkien faction dominated the Chinese Chamber of Commerce and the management board of the Chinese High School, the two most significant bodies that were meant to transcend dialect divisions. Undeterred, Aw made claims on leadership positions through his wealth, brashness and high social profile, and succeeded in gaining recognition as an overseas Chinese leader second in pre-eminence only to Tan Kah Kee. ${ }^{19}$ During the Sino-Japanese War from 1937 which expanded into the Second

${ }^{16}$ Ibid., p. 182.

${ }^{17}$ For an understanding of Aw's business strategies, see Peter Coclanis, 'Aw Boon Aw, Tan Kah Kee, and the big business in Southeast Asia', Southeast Asian Journal of Social Science, 23.1 (1995): 88-98; Sherman Cochran, 'Intra-Asian marketing: Aw Boon Haw's commercial network, 1910-1937', in Commercial networks in Modern Asia, eds. S. Sugiyama and Linda Grove (Surrey: Curzon Press, 2001), pp. 1-14.

${ }^{18}$ John S. N. Chan, 'An exploratory study of Aw Boon Haw's thoughts', Journal of the South Seas Society, 52 (Aug 1998): 28.

${ }^{19}$ John Chan Chuan Chye, 'Aw Boon Haw: An outsider's struggle for Chinese leadership in Singapore', Academic Exercise, History Department, National 
World War with the bombing of Pearl Habor, the overseas Chinese leaders gained prominence as Chinese nationalists by organizing antiJapanese activities, including the boycott of Japanese goods and the sending of funds to China in aid of the war effort. Aw, who was then stranded in Hong Kong, was deemed important enough to be invited to a meeting with the Japanese Prime Minister Tojo Hideki in Tokyo during July 1943. It was an invitation which he accepted and which certainly did not endear him to Tan and made him appear suspiciously as a wartime collaborator. ${ }^{20}$ When Aw died in 1954, his Singapore English-language newspaper called its versatile owner 'the king of philanthropy' and highlighted his Malayan rather than Chinese-related activities:

He was a friend of kings and prime ministers, of the big and the small. He was the patron and guiding light of sports associations too. Mr. Aw made his contribution to Malayan support in a hundred and one ways. He did not support one sport but all sport.... Financial success to Mr Aw meant only one thing. He had more money to give away to charity. ${ }^{21}$

His highly visible philanthropy aside, Aw Boon Haw flaunted his wealth in the ostentatious homes that he built. His residence in the European quarter of Singapore, built in 1927, was 'white all over, and has classical columns, and in the very centre of its façade, is set a large plaque depicting a tiger and leopard'. ${ }^{22}$ The building was designed by an American architect to resemble the official residence of the President of the United States, and was accordingly known as the White House. It was also home to Aw's magnificent jade collection, which was significantly augmented by purchases from desperate Chinese who were dislocated by the Japanese invasion of China in 1937. So famous was the collection that the White House also came to be called the Jade House. The seaside mansion which Aw

University of Singapore, 1988/89. The most telling incident that exposed Aw's brashness and ambition was his dispute with the Chinese High School management board over the arch situated at the school's main entrance. Aw had donated the money for building the arch, and had had the words 'donated by Aw Boon Haw and Aw Boon Par' inscribed, giving the impression that he had donated the money to build the whole school. The matter was taken to court, which ruled against Aw.

${ }^{20}$ For the controversy surrounding Aw's wartime record, see Huang Jianli, 'Entanglement of business and politics in the Chinese diaspora: Interrogating the wartime patriotism of Aw Boon Haw', paper presented at the international workshop on 'Asian diasporas: Revisiting the Chinese and South Asian experiences', 5-7 Apr 2004 .

21 Singapore Standard, 6 Sep. 1954.

${ }^{22}$ Lynn Pan, Sons of the yellow emperor, p. 175. 
Boon Haw built for his brother in Singapore was no less spectacular: a seven-dome structure that is said to be reflective of the Western Art Deco movement. ${ }^{23}$ The building was damaged beyond repair during the Japanese Occupation, and Aw submitted plans in $195^{1}$ to rebuild the residence along the lines of the imperial palace in Beijing, but the colonial authorities did not grant approval for this monumental aggrandizement. His alternative scheme to build the world's tallest pagoda ( 74 metres in height) also fell through when the Inland Revenue Department refused to grant a tax deduction for the project. ${ }^{24} \mathrm{He}$ was however, 'perhaps at his splashiest ${ }^{\prime 25}$ in the building of the Tiger Balms Gardens, the enormous garden complex surrounding the mansion he presented to his brother. Its grounds were initially opened to the public over the first three days of the Chinese New Year, and then all year round from 1937 onwards.

Aw personally directed his artisans in the construction of the Gardens, situated on a favourable hilltop overlooking the sea, a choice of location undoubtedly meant to draw in the positive elemental forces of Chinese geomancy to ensure that fortune would forever smile upon its residents. Observers both scholarly and popular have not failed to note its overlapping usages. It served as both family property and shrine, featuring the gigantic memorials built for Aw's parents, brother Boon Par, his son who passed away three years before he did, and finally, Aw Boon Haw himself. It also served as an advertisement space for himself and his products, with the ubiquitous tiger and leopard motifs appearing on arches and wrought iron fences and in the form of concrete animals, not to mention the stone jars of Tiger Balm ointment prominently positioned in scenes where they would offer relief from aches and pains.

Most significantly, however, Haw Par Villa was Aw Boon Haw's classroom, where as benefactor and paragon, he dispensed syncretic lessons on Chinese history, culture, folklore, religion, codes of morality and proper behaviour to its largely unlettered Chinese coolie visitors. The Buddhist conceptualization of repeated reincarnation cycles into the higher or lower order of beings in the after-life was reflected in stone sculptures on a spectacularly wide range of

${ }^{23}$ Sam King, Tiger Balm King: The life and times of Aw Boon Haw (Singapore: Times Books International, 1992), p. 307; Qu Rubo, Fenghuo suiyue (Singapore: Seng Yew Book Store, 1995), pp. 209-14, 239.

${ }^{24} \mathrm{Ng}$ Kim Teck, 'Tourist attractions: A study of Haw Par Gardens', Academic Exercise, Geography Department, National University of Singapore, 1984/85, p. 35 .

${ }^{25}$ Lynn Pan, Sons of the yellow emperor, p. 177. 
animals, from monkeys to turtles to carps. Some of these animal scuptures were overseen by statues of the Sakyamuni, Amitbha, Matreya and Ksitigarbha Buddhas, as well as the Goddess of Mercy. Numerous stone animals were dressed in human form, while others were apparently caught in mid-reincarnation from animal to human form (or perhaps vice-versa). Laozi, the founder of Daoism is kept company by the pantheon of Eight Immortals, associated with the Daoist paranoid search for immortality. Littered throughout the Gardens were the Daoist-related grottos with cloud patterns and nature-imitating rock gardens. Also represented were Confucius and the virtuous Jiang Ziya who had helped to usher in the Confucian golden age of the Zhou dynasty. A huge 45 -by-6-metre Virtues and Vices Tableaux liberally dispensed lessons on the importance of community projects, charitable works, gratitude, hard work, friendship and fidelity, while it condemned gambling, opium smoking, cabaret dancing, smuggling, stealing and indebtedness.

By far the most memorable tableau was the much-photographed Ten Courts of Hell, depicting the range of horrible punishments meted out to criminals and sinners by the ten kings presiding over the nether world. Vividly coloured figurines were depicted in the process of being disembowelled, dismembered, roasted, and boiled according to the nature of the evil deeds committed in their lifetimes. Positive exemplars were taken from the Confucian text on the Twenty-four paragons of filial piety. There was the tableau of Lady Tang ignoring the hunger cries of her infant and breastfeeding her wizened, toothless mother-in-law, and that of Wang Xiang lying on a frozen lake so that his body heat would melt the ice sufficiently for him to catch two carps for his sick stepmother's nourishment. Other iconic scenes from popular Chinese stories included the Peach Garden pact of brotherhood, where the three heroic warriors from the Romance of the Three Kingdoms swore to remain loyal and true to one another. There was also the Water Margin tale of Wu Song avenging his brother, a loving husband though not a good-looking one who had been poisoned by his wife and her paramour. The Villa was for the edification of the lowly immigrant Chinese, courtesy of one among them who had made good. Yet the very fact that Aw's didactic messages were so loud and insistent was an indication of not so much the grandeur of his ambitions as the insecurity of his claims of leadership in the Southeast Asian overseas Chinese firmament.

Aw Boon Haw's progeny added to the dimensions that could be discerned in the Gardens. Sally Aw Sian engraved her imprimatur 
on her father's legacy when she sponsored a glossy, definitive photographic volume of the two Tiger Balm Gardens. It included an interview in which she stated that Aw Boon Haw's impulse to build them had stemmed from his simple desire to provide recreational facilities for the people, given the shortage of public parks in the 1930 , and from his recognition of the Villas' value as an effective advertisement for the Tiger Balm products. ${ }^{26}$ The sponsored tome also proffered a nationalist angle, undoubtedly with an eye to postTiananmen China which was then conducting final preparations for the repossession of Hong Kong in 1997: Aw Boon Haw was said to have built the two public gardens and opened them for public access so as to 'give those Americans who toured around Hong Kong and Singapore a chance to know that even a small Chinese businessman [such as Aw himself] can have this kind of house, so that they will never cast us [Chinese] a scornful eye. It will also help Chinese to win face'. Apparently Aw had witnessed during one of his trips to the United States 'how the White men looked down on and despised [his Chinese] compatriots'. ${ }^{27}$

The managers of Aw's image as a Chinese nationalist also pointed to the presence in the Villas of the figure of Commissioner Lin Zexu, the patriot who had burnt the consignment of opium despite the British threat of retribution, sparking off the infamous Opium Wars. Furthermore, they claimed that the Tiger Balm Gardens had been the outcome of Aw's outrage at the offensive sign in the Shanghai bund park of the 1930s: 'No dogs or Chinese'. ${ }^{28}$ A reporter in the Aw family-owned newspapers suggested that the patriarch had been concerned that the overseas Chinese were mingling too closely with Westerners, and the Chinese traditional stories depicted in the Villas had been meant to remind them of their own culture. ${ }^{29}$ Apparently, a swimming pool built in 1931 , which Aw later also turned into a public facility, had a sign that specified 'no foreigners allowed' ${ }^{30}$ If such a

${ }^{26}$ Judith Brandel and Tina Tuberville, Tiger Balm Gardens: A Chinese billionaire's fantasy environments (Hong Kong: The Aw Boon Haw Foundation, 1998), citing an interview with Sally Aw Sian conducted on 14Jan. 1994, p. 17.

27 Ibid., p. 202, fn. 2, citing Aw Boon Haw's own words as reported in Heung Tao Jih Pao, 13 Mar. 1943.

${ }^{28}$ Ibid., p. 17.

${ }^{29}$ Ibid. Sam King, who was interviewed on 27 Nov. 1995, is a former journalist who had worked for Aw's newspapers. He served as a key assistant to Aw's son Aw Hoe and wrote the popular biography, Tiger Balm King: The life and times of Aw Boon Haw.

${ }^{30}$ Lianhe zaobao, 26 Apr. 2001. 
sign had indeed existed, its purpose would have been symbolic: it is not likely that the British ruling race would have cared to mingle with the Chinese in a public swimming pool. The colonial rulers were certainly not mindful of the Tiger Balm Gardens being an anti-colonial space. In fact, Aw was conferred the Order of the British Empire in May 1938. The British also awarded him the Associated Knight of the Venerable Order of St. John of Jerusalem in $195^{0},{ }^{31}$ a time when the empire was on the decline and Singapore on its road to independence.

\section{The Villa post-Aw Boon Haw: The loss of aura}

Aw Boon Haw stipulated some months before his unexpected death in 1954 that the Haw Par Villa should be opened to the public free of charge and not be sold or converted into a private possession for twenty years. Up to the mid-1980s, the grounds remained largely unchanged. His nephew Aw Cheng Chye, who was Boon Par's son and who took over the helm of the Singapore Haw Par business empire, added to the uncle's inimitable concrete exhibits, until his own death in 1971 . Though Cheng Chye's contributions were far more prosaic, they were refreshingly international. He installed icons of countries to which he had travelled, such as Italy (1964, discus thrower in Olympian pose), Spain (1964, flamenco dancer), Australia (1961, kangaroos, koalas and black swans), New Zealand (1965, Maori tiki and two kiwis), Thailand (1965, classical dancer) and Indonesia (1970, garuda), to continue the self-assumed responsibility of broadening the minds of the Singapore Garden's visitors. The biographical overlay was also retained: the Villa's US Statue of Liberty $(1967)$ bore the inscription 'Farleigh Dickenson University, New Jersey', which had conferred upon Cheng Chye an honorary Doctorate of Laws. ${ }^{32}$ The opening ceremonies of these 'international corners' were often diplomatic coups for the family, with the ambassadors concerned and government ministers in attendance. The Minister of Culture and Social Affairs Othman Wok remarked at the opening of the American corner that the latest addition made the Villa not only alive by constantly responding to the spirit of the times, but also reflected a tolerant society. $\mathrm{He}$

31 Victor Sim, ed., Biographies of prominent Chinese in Singapore (Singapore: Nan Kok, 1950), p. 4; Lee Kam Hing and Chow Mun Seong, eds., Biographical dictionary of the Chinese in Malaysia (Petaling Jaya: Pelanduk Publications, 1997), p. 2.

${ }^{32} \mathrm{Ng}$ Kim Teck, 'Tourist attractions: A study of Haw Par Gardens', p. $5^{1}$. 
expressed the hope that many more such corners would be added to the Villa 'to reflect the remarkably cosmopolitan content' of Singapore society, as well as the country's desire to maintain cordial relations with the maximum number of friendly nations. ${ }^{33}$ Despite its weighty role as a symbol of an open society, the Villa did not abnegate its function as a three-dimensional advertisement billboard. Aw Cheng Chye displayed a modicum of his uncle's élan when he placed stone jars of Tiger Balm within easy reach of the concrete sumo-wrestlers he had constructed in the Japan corner (1960).

All this time, the Villa remained a popular park with locals, and when tourism began to develop, with foreign visitors as well. A survey conducted in 1983 by the Singapore Tourist Promotion Board ranked it third in popularity after Chinatown and the island resort of Sentosa; it attracted visitors from Japan, Switzerland, the United States, Australia, New Zealand and Taiwan. ${ }^{34}$ Tourist guidebooks seemed to be almost competing to sell it as kitsch: 'grotesque statuary in appalling bad taste', 'a landscape nightmare', 'garish', 'decidedly gruesome' were typical descriptions that have been brandished to attract visitors. ${ }^{35}$ The Singapore Tourist Promotion Board, formed in 1964 whilst Singapore was still part of Malaysia, adopted 'Instant Asia' as the country's tourism imagery in the 1960 s and 1970s, invoking 'a kaleidoscope of Asia with one big concentration and happy coexistence of different cultural manifestations in people's dress, food, traditions, customs, languages, religions, architecture and attitudes' ${ }^{36}$ 'Instant Asia' also fitted in with nation-building revolving around the concept of multiracialism, which judiciously sought to de-emphasise the Chineseness of the country in order to defuse the tensions of ethnicity both domestically and in the region that had escalated during Singapore's Malaysian years (1963-65). In this political climate, Haw Par Villa was initially left on its own to draw visitors. One popular feature that attached itself to the place took the form of Indian snake charmers who stationed themselves at the entrance, and charged visitors a fee for being photographed with the reptiles. Tricksters who, with sleight of hand would move three cups around on a small wooden table and accept wagers placed on which cup contained a ball,

33 The Straits Times, 25 Dec. 1967.

${ }^{34}$ Ibid., 17 Oct. 1984.

${ }^{35}$ Judith Brandel and Tina Turbeville, Tiger Balm Gardens, p. 14.

36 T. G. Chang, 'From instant Asia to multi-faceted jewel: Urban imaging strategies and tourism development in Singapore', Urban Geography, 18.6 (Aug.-Sep. 1997): $54^{8-9}$. 
did not necessarily have the permission to ply their trade, but were nevertheless popular with visitors. Operators rented out tacky Chinese opera-looking costumes as traditional Chinese attire for those wishing to be photographed wearing them. ${ }^{37}$ The Villa provided room for the ingenuity of such petty freelancers to heighten the interest of visitors.

By the 1970s, however, the Villa's days as a privately-owned public attraction were numbered. With the decline in the family's fortunes from an ill-considered transfer of its stakes to the Slater Walker investment group and Aw Cheng Chye's death shortly thereafter in 1971, the Villa no longer enjoyed the unstinting resources and attention that Aw Boon Haw and his nephew had lavished. The family was reluctant to continue paying for its upkeep, and by 1979, decided to hand the Villa over to the state so that the Singapore Tourist Promotion Board could be responsible for its maintenance thereafter. However, complications arose regarding its existing lease and the family's insistence that admission to the Villa should remain free of charge. While the parties were locked in what appeared to be a deadlock, the condition of the Villa deteriorated. Letters to the press complained that it was an embarrassing aberration to the otherwise clean and green Singapore. ${ }^{38}$ Only four workers were employed to fight the elements and vandals. Paint was peeling off some sculptures and there were layers of dirt and dust on them. ${ }^{39}$ Finally the state cut the Gordian knot in 1985 by invoking the Land Acquisition Act and taking over the property. The following year, the Aw family made a gift of all the exhibits and structures in the Villa to the nation, with the proviso that the Villa should retain its name and that the family memorials it contained be inviolate. ${ }^{40}$

The use of legislation to enforce the acquisition of Haw Par Villa was done on the recommendation of the Tourism Task Force formed in 1983 to undertake a major review of the approaches taken in marketing Singapore as a tourist destination. With the oil crisis during the early 1970 , the rate of growth in the number of tourists to Singapore had steadily declined. Tourist arrivals actually fell for the first time in 1983 . The pace of modernizing the urban landscape

${ }^{37}$ Photographs of these activities can be found in $\mathrm{Ng}$ Kim Teck, 'Tourist attractions: A study of Haw Par Gardens', pp. 79-8o; 'Site and mythology study of Haw Par Villa', unpublished report commissioned by Fraser and Neave (s) Privated Limited, Nov. 1985 .

38 The Straits Times, 20 May 1983.

${ }^{39}$ Ibid., 29 Oct. 1984.

${ }^{40}$ Ibid., 12 Oct. 1986. 
was identified as the cause of this malaise, and one of the themes that the Task Force promoted to reverse the slide was 'Exotic East', which included the rejuvenation of Haw Par Villa. The Board initially intended to restore the old and cracked exhibits and stage Chinese operas, puppet shows, story-telling sessions and magic shows. ${ }^{41}$ However, its sights were raised much higher when Economic Research Associates, which had conducted feasibility studies for Disneyland in the United States, recommended in 1985 that the Villa be upgraded into a world-class tourist attraction by transforming it into the only Chinese mythology theme park in the world, with state-of-the-art technology that would 'bring the Chinese figurines to life'. ${ }^{42}$ By this time, the Singapore government through its programme of 'inventing nativity' had moved into celebrating its people's cultural roots as embedded in Asia's major civilizations, especially the Chinese one, and Haw Par Villa had come to be seen as iconic of the 'Exotic East'.

A local consortium International Theme Parks, formed by the beverage giant Fraser \& Neave and book publisher Times, won the tender to develop and manage the mega-million 'adventureland of Chinese folklore', which involved closing the site for two years. ${ }^{43}$ The new Haw Par Villa was to be 'a living testimony of the rich Chinese heritage, resplendent in pageantry and picturesque sights', blended with Western technology, and designed for visitor involvement which would stretch their stay there from half an hour to three hours and extend their visit to Singapore by half a day. ${ }^{44}$ 'Watch out, Disneyland' was the confident projection of the Villa's future. ${ }^{45}$

\section{Cultures plebeian and 'imperial': In search of Chinese nativity}

The public sentiments about Haw Par Villa which had surfaced at that point of transformation highlighted that the era of Aw Boon Haw was one that did not sit comfortably with the Singapore of the 1980 . Even those who championed the preservation of the Villa rather than its reconstitution as a Disney theme park adopted a qualified, defensive position in their arguments. A Straits Times editorial stated, for instance, that the Villa 'was not exactly a national treasure, or

${ }^{41}$ Ibid., 10 Feb. 1985 .

${ }^{42}$ Ibid., 5 Aug. and 2 Oct. 1985 . The ERA report submitted in Jul. 1985 played a crucial role in locking in place the mindset of policy makers for the next decade.

43 Ibid., 30 Jul. 1988.

${ }^{44}$ Business Times, 29 Apr. 1986.

${ }^{45}$ The Straits Times, 4 Jul. 1985 . 
what most Singaporeans regard as part of their nation's heritage. But grotesque as parts of it were-and deliberately so-it was both a part of the visitor's Singapore and part of the young Singaporean's growingup experience'. The editorial expressed embarrassment about the vulgar aesthetics of the nouveau riche of Aw's generation. Precisely by disavowing its plebeian historical legacy for the Singapore of the 1980 s, the newspaper allowed itself to take a carefully patronizing stance towards the Villa:

It may not be an image about what we are particularly proud... it has no distinct historical value, but it certainly has a remarkably distinctive style. Not everyone may care for the colour scheme or the themes of the tableaux, or the quality of the figure work. But where else can the Singaporean and the foreigner find such a rich and sometimes vulgar representation of man's imagination, dreams and fears? ${ }^{46}$

The disavowal of Haw Par Villa as part of Singapore's national heritage subscribes to the Orientalist perception that the largely coolie past did not possess practices of cultural worth, unlike Japan's, for example. ${ }^{47}$ The overseas Chinese culture that it embodied also proved to be too vulgar for the two Beijing professors, aged 59 and 64 , who were recruited by the theme park project as consultants on history, culture and architecture. Despite being newly liberated from the puritanical aesthetics of the Cultural Revolution, they argued that the 'scenes of sex and gore' were too sexually explicit or violent for children, and should therefore be removed. ${ }^{48}$ A Straits Times reader seconded a 'thorough cleaning up' of the Villa, for he and his friends would visit 'out of an interest in the culture, history and beliefs of the Chinese, which is my race', which to him evidently did not include the 'harmful superstitions' exhibited in the Villa. ${ }^{49}$ Another reader disagreed with the professors, noting that he himself had not grown up to be a womanizer or a sadist despite having gawked at the offending exhibits in his youth. ${ }^{50}$ One of the displays that the Chinese professors found objectionable depicted the monk Tang Zeng on his journey to obtain the Tripitika, the Buddhist scripture, while resisting the advances of sex-hungry women sent to distract him. An old-hand in journalism happened to recall that around 1951, the Singapore

\footnotetext{
${ }^{46}$ Ibid., 23 May 1979.

47 Ien Ang and Jon Stratton, 'The Singapore way of multiculturalism', p. 70.

48 The Straits Times, 4 Nov. 1986.

${ }^{49}$ Ibid., 11 Nov. 1986.

${ }^{50}$ Ibid., 4 Nov. 1986.
} 
Buddhist Federation, responding to similar objections raised by some Buddhists, had urged for the two almost naked women figures in the temptation scene to be 'dressed'. Aw Boon Haw in compliance then ordered some attire to be painted on, even though the paint job did not completely dampen sexual suggestiveness. The journalist concerned pointed out that those familiar with the popular Chinese classic Journey to the West would surely know that the saintly monk in question had eventually overcome the temptation, and thus the exhibit actually delivered 'a glorious triumph of Good over Evil in its most devastating form'. ${ }^{1}$

The didactic and moral import of the Haw Par Villa exhibits, however, could not completely make up for their inadequacies as representations of exotic Chinese culture as far as their new owners were concerned. Battaglia Associates, an offshoot company of Walt Disney Productions ${ }^{52}$ that won the contract for fleshing out the Chinese mythology theme park concept, proposed a number of additions to enhance the Villa's authenticity, which were drawn from the company's interpretation of imperial Chinese history and culture. This included the 'Imperial Path' which was to be a journey through centuries of written history from the Shang to the Qing Dynasties, with visitors being moved along in little carts or trams winding their way through shallow flooded tracks. ${ }^{53}$ There was also to be a Beijing palace complex, with a five-storey Chinese pagoda and a building inhabited by a Confucius robot writing calligraphic verses from his classical text Golden Mean and preaching them to visitors in a melodic computergenerated voice. Another proposed section would display oriental antiques, costumes and artefacts on loan from museums in China, all within a 'recreated setting of a Chinese palace'. The proposed 'Singapore Sings' theatre with a giant cybernetic Chinese panda singing a duet with his small cousin, the brown bear, would reflect the positioning of Singapore as the cultural inferior without meaning to do so. ${ }^{54}$ These proposed schemes to introduce a more respectable stock representation of Chinese imperial culture to 'upgrade' Haw Par

${ }^{51}$ Ibid., 8 Nov. 1986. This is T. F. Hwang's column on 'Down the Memory Lane'.

${ }^{52}$ Headed by Richard Battaglia, the company has a long string of global credentials: Marine World Africa in the US, Expo 86 in Vancouver, Lotte World in Seoul, Entertainment City in Kuwait, Clontarf River Adventure in Perth, Frontier City in Orlando, Land of Fun in Ecuador, Dickens' London in Britain, Muskoka Steam Park in Canada and Aero World in San Diego. See Houston Chronicle, 7 Dec. 1986.

53 The Straits Times, 29 Apr. 1986.

${ }^{54}$ Ibid., 23 Jul. 1986; Business Times, 23 Jul. 1986. 
Villa were rendered unnecessary when a parallel project was launched to build a replica Chinese capital city of the Tang era to depict the glory of Chinese history.

The Chinese culture that the Singapore authorities preferred to identify themselves with was that of the traditional literati, not the folk beliefs and practices of the overseas Chinese immigrants. Confucianism and the glorious dynasties of China had become the frame of reference for what it meant to be Chinese. In 1982, religious knowledge was introduced in the school curriculum, and Confucian Ethics was a much-touted option. The Institute of East Asian Philosophies was set up within the campus of the National University of Singapore to conduct related research and a high-profile international panel of Confucian scholars was appointed as its advisors. At the same time Chinese ethnicity was deemed to be synonymous with inherent Chineseness. When the Hong Kong middle classes were in the throes of insecurity over the impending 1997 return of the British colony to the mainland government, Singapore threw them a 'lifeline' with liberal offers of permanent residence and citizenship options. ${ }^{55}$ The intention was to offset the number of Singapore Chinese who had emigrated and those who had failed to marry and reproduce, and thus to maintain the racial balance in Singapore. ${ }^{56}$ Among the 'highquality' personalities who were attracted to Singapore's courting was Hong Kong television magnate and developer Deacon Chiu, who owned and managed Hong Kong's Song Dynasty Village built in 1979, a theme park recreating that period of Chinese history for tourists and the film industry. Chiu got approval from the Singapore authorities to build the Tang Dynasty Village cultural theme park, an 'entertainment city duplicating the grandeur of China's greatest era' which was to be twenty times larger than its Hong Kong counterpart. ${ }^{57}$

'Although Singapore is less than two centuries old, visitors can venture back some 1400 years in history to the golden age of classical Chinese culture' ${ }^{58}$ This feat of anachronistic paradox was to be achieved by simulating and replicating the Tang dynasty (618-9o6) in Singapore, at a time when China was still not well-prepared for mainstream tourists. The Tang Dynasty Village featured 'a period where people were educated, cultured, and had a taste for the arts.

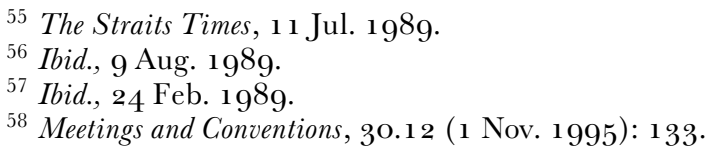


Trade and foreign relations also flourished, drawing traders and diplomats to the Middle Kingdom, ${ }^{59}$ It encompassed a miniature of Changan, the Tang capital, with a commercial district containing 108 stalls representing the number of trades of that era, as well as an underground palace, and featuring terracotta warriors, horses and chariots, 'live' mandarins in silk robes, as well as court ladies in flowing costumes. ${ }^{60}$ The complex also included three television and movie studios that would cater to the production of two to three films a year for the Hong Kong, Singapore, Taiwan and China markets. Critically acclaimed American film-maker Peter Wang spoke confidently of Singapore as a film centre that would overtake Hong Kong, where the industry was pronounced to be gloomy, due to actors and directors wanting to migrate on account of 1997 , while he found Taiwan to be 'too repressive, and audiences there were less interested in art films'. ${ }^{61}$ The People's Republic of China needless to say was even more stifling. Wang's reported assessment, especially of Taiwan, could certainly be questioned, but its purpose was to clear the ground for Singapore to be the most modern and by that token the most meaningfully Chinese of them all.

Nevertheless, theme-park authenticity had to be drawn from China and little expense was spared for the Tang imperial city project. Two million pieces of 'green bricks' and another million pieces of granite slabs, slates, roof tiles and jade-coloured eaves were imported, and one hundred experienced craftsmen brought in from China to work on the building. Flora native to China were transplanted in equatorial Singapore. About 6o actors and some long-haired Bactrian camels were imported from China to give authenticity to the activities of merchants and performers along the quaint cobbled streets. ${ }^{62}$

The revamped Haw Par Villa and the Tang Dynasty Village were the complementary faces of the same coin, currency that purchased for Singapore the Sinic roots that its leadership hankered for. While the former dwelt on folk mythology and culture and the latter offered a popular interpretation of imperial grandeur, both were presentations of generic Chinese culture commodified into theme parks. This was Singapore's claim to be the heir to the greatness of the Middle Kingdom, as well as serving as the surrogate authentic China, for it

\footnotetext{
59 The Straits Times, 24 Feb. 1989.

${ }^{60}$ Ibid., 24 Feb. 1989.

${ }^{61}$ Ibid., 20 Aug. 1989.

${ }^{62}$ Ibid., 9 Dec. 1989.
} 
was to be the Chinese population on this island state who would be the modern Confucian gentlemen of the future. Such men would disavow any connection to Aw Boon Haw and the crass overseas Chinese opportunists and philistines, and accordingly those aspects of Haw Par Villa that were part of a biographical landscape, such as the tiger and leopard insignias, as well as including the Tiger Balm ointment and name, were to be eliminated. Even made more out of place by the purification process to get rid of the eclectic accretions charting Singapore's social trajectories were Aw Cheng Chye's international corners, and most certainly the intrusive Indian snake charmers. The refashioned Villa opened its gates on 2 October 1990 as 'The Dragon World'.

\section{Enter (and exit) the dragon: Death of a schizophrenic Disney theme park}

With Aw Boon Haw removed as the pivot, the Tiger Balm Gardens displays were reshuffled so as to form a new narrative. A dragon was installed as the reigning motif. The iconic Chinese mythological creature displaced Tiger Aw, and at the same time was evocative of the dragon economies of Asia that were then fuelling the development of the Asia-Pacific rim as the growth engine of the international economy. The main feature of the theme park Dragon World was a hybrid of the old and new: the Lady White Snake, the Eight Immortals and the famous Ten Courts of Hell tableaux were literally swallowed up by a 6o-metre dragon, whose mouth formed the entrance to a China Tales boat ride traversing its length with a guide giving an account of these stories as the visitors sailed through. The thrills and spills of a Disneystyle theme park experience were provided by the Wrath of God flume ride, supposedly driven by the Water Spirits. Newly constructed were three air-conditioned, indoor theatres and two open-air ones. The huge indoor theatres were heavily wired with 'specialized technology such as fibre optics, strobe lights, air-cylinder animation and cybernetics,' with the aim of achieving a 'meeting of Eastern mythology and Western technology'. ${ }^{63}$ One of the theatres was named 'Legends and Heroes', which featured a robot dressed up as an old Chinese scholar relating the stories of archer Hou Yi and the ten suns, Lady

${ }^{63}$ Ibid., 3 o Apr. 1986. 
White Snake and Boy Hero Nezha. Another, 'Creation of the World', communicated with flashing strobe lights, laser beams and booming sound effects the Chinese version of the creation myth involving the mythological activities of Pan $\mathrm{Gu}$ and $\mathrm{Nu}$ Wa. A third, 'Spirit of the Orient', was essentially a high-tech, 9-screen multi-video presentation of the stories behind the Chinese Mooncake Festival and Dragon Boat Race. The open-air theatres hosted puppet shows, acrobatic displays, stilt-walkers as well as live performances on 'Mother Earth and Tale of Elements', with actors jumping to the beat of music.

The park emphasized its strict concern with reflecting Chinese myths, legends, culture and virtue, achieving, in other words, 'commercial authenticity' with 'the best of Disneyland without... pandering to Western influences'. ${ }^{64}$ The Straits Times duly posed the obligatory Occidentalist question: 'Would theme parks impart an undesirable Western influence'? The glib reply attributed to university academics was that on the contrary, more theme parks on Asian culture and tradition were needed as Singapore children did not seem to be familiar with them. Dragon World was to be no mere commercial revenue-churning project like its Western counterparts, but was deemed to have educational value, imparting moral lessons promoting filial piety and awareness of retribution for misbehaviour. ${ }^{65}$

Dragon World was expanded to five times the original size of the Aw Villa, to 9.5 hectares of land at a cost of 80 million dollars, and 1 million visitors were projected within the first year of opening. ${ }^{66}$ The theme park made a small profit in the first year, but from then on visitor numbers declined steadily as its novelty wore out. The theme park owners were prepared to invest another $30-40$ million dollars to give the park the necessary economies of scale to make the entire project profitable. ${ }^{67}$ For three years they also tried to develop the seafront site abutting Dragon World into a water-based theme park to be named Admiral Cheng Ho Wharf, after the famous Chinese Muslim eunuch who had led seven voyages (1405-1433) of spectacular armadas 600 years ago to Southeast Asia and beyond. Rather than a celebration of Singapore's historical location in the region which had been visited by the admiral, the Wharf was to be an extension

\footnotetext{
${ }^{64}$ Business Times, 22 Jul. 1990.

65 The Straits Times, 10 Nov. 1991.

${ }^{66} \mathrm{Ibid}$

${ }^{67}$ Ibid., 18 Dec 1992.
} 
of the Dragon World and yet another piece of China. The proposed designer-built fifteenth-century Ming dynasty Chinese port was to be connected to Haw Par Villa via an overhead bridge and serve as the Villa's hinterland of activities. On the drawing board were plans for three replicas of Cheng Ho's large junks, to be used as restaurants, bars or lounges, and a floating stage for performances. The shore was to be modelled on the Chaozhou waterfront houses of the admiral's time, with Chinese pirates swaggering about and lining their plunder along walkways. A colourfully-lit, water-spewing dragon would be constructed in the seafront. ${ }^{68}$ However, a major tussle for land erupted between government agencies, a rare occurrence in Singapore, and it took the Prime Minister's Office to rule against the project and reserve the land for new container port facilities. ${ }^{69}$ Admiral Cheng Ho had evidently lost the seafront battle.

Dragon World was a financial disaster fairly much from its opening in October 1990. A revamp was launched in 1995-97, and the appellation 'Tiger Balm Gardens' was revived, with 'Dragon World' abandoned along with the boat ride through the creature and all the talk of using high technology. Instead, an audio-visual presentation of the Aw brothers was introduced. The effort was billed as 'bringing back the authentic version... the way most Singaporeans remember it,' which nevertheless involved the immediate importing of 67 statues

${ }^{68}$ Ibid., 20 Jul. 1988.

${ }^{69}$ Business Times, 18 Dec. 1992. The agencies involved were the Jurong Town Corporation, Urban Renewal Authority, Science Park, and Port of Singapore Authority. In the 2005 celebration of the 6ooth Anniversary of Cheng Ho's first historic voyage, dominated partly by the frenzy over Gavin Menzies' controversial I42 I: The Year China Discovered the World (London: Bantam Press, 2002), several government agencies and Chinese businessmen in Singapore apparently regretted the termination of the wharf project more than a decade ago and had to search for new ways and means to link up once more with the Admiral's voyages. The celebrations reached its height in August with simultaneous hosting of the '1421: The Year China Sailed the World Exhibition and Zheng He Festive Village' at the Marina Promenade, the 'Zheng He \& Maritime Asia Exhibition' hosted at the National Library, and an international academic conference on 'Maritime Asia and the Chinese Overseas, 1405-2005' at the Regional English Language Centre, all involving the Singapore Tourism Board. The Straits Times, 25 Mar., 26 May, 11 Jun., 3oJun. and 19 Aug. 2005. For the controversy surrounding the first, see Geoff Wade's letter to the International Herald Tribune posted on Singaporeheritage@yahoogroups.com, 25 Jun. 2005, The Straits Times, 7 Jul. and 22 Aug. 2005. Geoff Wade has been highly critical of Gavin Menzies' claims and he subscribes to the interpretation that Zheng He's trips were not 'voyages of friendship' but rather 'aggressive attempts to achieve a pax Ming in the Asian maritime realm'. See his 'The Zheng He Voyages: A Reassessment' in Journal of the Malaysian Branch of the Royal Asiatic Society, 78.1 (Jun. 2005): 37-58. 
from China to enhance the appeal of the Ten Courts of Hell. ${ }^{70}$ Entry charges were drastically slashed to attract visitors, but the losses were as much as 31.5 million dollars by 1998 , in addition to the 80 million dollars start-up investment. ${ }^{71}$ The operator finally gave the theme park up in March 2001, two years after the Tang Dynasty Village closed its doors.

From the start, Dragon World had critics coming from different directions. Travel operators warned that it was overpriced, and that the organizers had oversold what the theme park had to offer. They had been led to expect a much greater transformation than was the case, and more exciting activities than were available. ${ }^{72}$ Their reservations were well-founded. On weekends, long queues waited in the hot sun for the two rides. 'We had the impression that the new park was going to be an oriental version of Disneyland', some travel industry representatives complained. ${ }^{73}$ On the other hand, others were disdainful of the incongruity of the Americanized presentation in the Chinese mythological theme park. They scoffed at the beat of American music which accompanied what were meant as narratives of Chinese myths ${ }^{74}$ as well as of the American accents of the voice recordings used. ${ }^{75}$ In addition, the meshing of technology and Chinese content did not work: visitors found that the boat ride unsatisfactorily 'whizzed them through' the Ten Courts of Hell and other exhibits inside the dragon, and they were unable to have a good look at them. ${ }^{76}$ There were complaints by visitors of the bad English being spoken by attendants at the rides and shows. One local visitor found her China Tales boat ride 'tortuous' with the boat attendant being hardly able to 'string a sentence grammatically' in narrating the tales, including those relating to the Courts of Hell tortures, let alone bring the stories to life. The gushing sound of the water did not help those who wanted to

70 The Straits Times, $3^{1}$ Jul. and 13 Dec. 1995.

${ }^{71}$ Business Times, 29 Apr. 2000.

${ }^{72}$ Evidently, Singapore's population and visitor numbers have been too small to sustain a Disney-type theme park as a single Disneyland attraction can cost up to US\$ 100-plus million. This piece of wisdom was shared by the manager of Volcano Land, an attraction on the island resort of Sentosa, and was offered in defence against criticisms by visitors that its simulated volcanic eruptions were not earthshaking enough. The Straits Times, 31 Mar. 1999.

${ }^{73}$ Ibid., 24 Oct. 1990.

${ }^{74}$ Ibid., 28 Oct. 1990.

${ }^{75}$ Ibid., 7 Oct. 1990.

${ }^{76}$ Ibid., 5 May 2000. 
listen more carefully to the explanations of Chinese culture either. ${ }^{77}$ Yet, Chinese-speaking visitors were disappointed to find that there was too much emphasis on English in the presentations.

Evidently, the Singapore theme park failed to satisfy either East or West. To one constituency, Dragon World fell far short of the scale and variety of the Disney experience; to the other, the American sounds in the Chinese theme park were disconcerting. To Englishlanguage speakers, the language skills of Singaporeans who took on the relatively low level jobs of being boat ride guides were an embarrassment, ${ }^{78}$ they would in all likelihood also not have the fluency in Mandarin to pass muster with native Chinese speakers. This had been borne out by the Tang Dynasty Village's experience: 'Our in-house tour guides try to talk about Chinese history in a fun way. But realistically, how many Singaporeans [can be] expected to express Chinese history in a fun and entertaining way?' Similarly, the Dragon World guides were not expected to be able to carry out the cultural performances and activities either. 'Native' Chinese from 'overseas' had to be employed, making the cost of running of any China-related theme park prohibitive. ${ }^{79}$ In the end, Dragon World could only inadequately mimic the West and East: Singapore clearly did not have the financial resources to create its own Disneyland, nor the cultural capital to be a miniature China. What was less clear was how to move on after the failure of the theme park.

\section{Defenders and detractors: A debate on culture and politics}

While the two Chinese theme parks became an object lesson invoked by those critical of contrived, large-scale tourism projects, ${ }^{80}$ the

${ }^{77}$ Ibid., 1 Jul. 2001.

${ }^{78}$ While a highly-educated English-language speaker like the former Minister for Information and the Arts George Yeo continues to be rankled by a British army major's compliment that Singaporeans were a 'well-colonized people' on hearing Yeo's fluent English as a student in England, (cited in Ien Ang and Jon Stratton, 'The Singapore way of multiculturalism', p. 83), a 'community-led initiative' was launched in 2000, with the support of the Singapore government to promote the use of 'good English' among Singaporeans (The Straits Times, 25 Jul. 2003). The current on-going 'Speak good English movement' is aiming at the eradication of the pervasive use of 'Singlish', the hybridized Singaporean version of English that is laced with Chinese, Malay and Tamil expressions and syntax.

79 The Straits Times, 27 Mar. 1999.

${ }^{80}$ Ibid., 26 May and 23 Jun. 2000. 
Singapore Tourism Board remained unrepentant. Just before the exit of Dragon World, it continued to set about sourcing for a 'big-name' to take over Haw Par Villa, still pronouncing that 'the code word is mega theme park' and hinting of possible interest from Disney and Universal Studios, world-class operators who would have 'the best chance of sustaining their proposals in the long term'. ${ }^{81}$ There was not a single serious bid in response to the international tender that it put out in December 2000.

Singaporeans were well aware that with the failure of Dragon World, the fate of Haw Par Villa hung in balance. Both The Straits Times and the Chinese language paper Lianhe zaobao canvassed readers' views on what should be done with it. The former conducted a straw poll within a week of the official announcement of the demise of the Chinese mythological theme park. Of the 8 o people polled, 49 thought that it should be closed down for good: 'it is incurring massive losses' and 'it is boring' were the reasons given. A retiree voiced more specifically modernist objections: 'It is awful. The park is not separating legend from history'. ${ }^{82}$ The Straits Times itself, resigned to what it considered the inevitable in Singapore, where 'hard calculations on commercial viability and land use can result in Haw Par Villa being demolished', suggested that at least the sculptures should be rescued and relocated to the Chinese Garden in Jurong.

The most comprehensive arguments for preserving the Villa were marshalled by the Heritage Society, a civic group. ${ }^{83}$ It pointed out that the restoration of the Villa to public park status would be an important gesture reaffirming the value placed on public spiritedness such as that which had been displayed by Aw Boon Haw. This was necessary as globalization had resulted in a widening of the income gap. The more fortunate thus had a certain responsibility to the rest of society to balance profit-centred private interests and public welfare, and in this Aw was posited as a model. Allied to this was the argument that Haw Par Villa was a marker of cultural values that earlier generations of Singaporeans had held dear, such as charity, honour, and trustworthiness, arguably even more pertinent than ever in the global economy. The Villa's legacy contained in its moral and educational content thus constituted an important part of Singapore's cultural heritage. Finally, the Society asserted that Haw

\footnotetext{
${ }^{81}$ Ibid., 14 Oct. 2000.

${ }^{82}$ Ibid., 5 May 2000.

${ }^{83}$ Ibid., 3 Sep. 2000.
} 
Par Villa was about fun, play and imagination, celebrating in its unique way qualities like quirkiness, individuality and playfulness, which it claimed were not easy to come by in present-day Singapore. The Heritage Society's defence centred on the Villa as one of the remaining few symbolic assets that could be utilized for nation building. It used the language of pragmatism to address what the authorities themselves had pronounced were lacking in Singaporeans: a sense of civic responsibility, personal moral values, and creativity. The latter value was regarded as the hallmark of the new entrepreneur, which Singapore urgently needed for survival in the new information-age economy. Hence, the argument put forth was that the Villa could contribute to making Singapore a fun place to live in, and thus attract high-value added professionals to work and remain in Singapore as well as contribute to upgrading its economy. The Heritage Society carefully chose to 'sell' the Villa as answering the practical needs of contemporary Singapore as defined by the authorities themselves.

A columnist from the Straits Times was less subtle. He was sure that there was a punishment for disrespect in the Ten Courts of Hell awaiting those who advocated demolition of the Villa: 'Why prop up a 67-year old loss-making, garishly-garbed and bizarre relic? [It is] for the same reasons that one does not consign one's grandmother to the trash-can when she stops making sense'. ${ }^{84}$ Nevertheless, even he saw the need to suggest that it was possible for 'grandmother' to 'make the accountants happy' with interactive displays, live opera performances, a museum of Chinese artefacts, a dancing panda-after all, Las Vegas worked simply because it was 'kitschy, tacky and downright gaudy'.

The Chinese press gave its readers less rein on the issue, publishing only suggestions on how to give the Villa a new lease of life. ${ }^{85}$ These included turning it into a full-fledged, miniature Chinese mythology or cultural garden with the addition of scenes from the Water Margin and Dream of the Red Chamber, ${ }^{86}$ as well as a suggestion to strengthen the elements of overseas Chinese folk culture by adding figures of deities popular with the migrants such as the sea goddess $\mathrm{Ma} \mathrm{Zu}$ and Tua Pek Kong (Dabo gong), as well as building a syncretic ConfucianistBuddhist-Daoist temple at the highest point. ${ }^{87}$ A columnist in the Lianhe zaobao sententiously took issue with the negative comments

\footnotetext{
84 Ibid., 5 May 2000.

${ }^{85}$ Ibid., 13 May 2000.

${ }^{86}$ Lianhe zaobao, 21 May 2000.

87 Ibid., 13 May 2000.
} 
that had emerged from The Straits Times straw poll, calling them 'specious'. He faulted as bigotry the opinion that Haw Par Villa gave the impression that the Chinese were superstitious, asserting that those who were Buddhists and Taoists would certainly not hold such a view. He also took umbrage at a comment that the Villa should follow the example of the popular Botanic Gardens and not charge admission fees, as free public access had in fact been an original feature of Haw Par Villa. Finally, he disagreed with the view that the Villa was outdated, arguing that Chinese culture and history was of such vintage and depth that there were endless possibilities to draw on to establish it as a manifestation of Chinese heritage. The Western experts responsible for the high technological elements had insufficient understanding of Chinese culture, even after professing to have read two hundred or more books on the subject when they took up the Dragon World project. They had ended up causing 'serious internal injuries' to the Villa from the 'poison' they had unwittingly introduced. ${ }^{88}$

The discourse in the local Chinese-language newspaper at the turn of the millennium was of righteous indignation on the part of an aggrieved party. The Villa was Chinese cultural space, and that was reason enough for it to be inviolate. There was no need to indulge in the elaborate sophistry of the Heritage Society, nor the carefree tone of the qualified support in the English-language press for what they had deemed to be an aesthetically embarrassing Singapore legacy. The Villa was treated as a purely Chinese Singaporean issue, with both newspapers not featuring views on its future from Malay and Indian Singaporeans, in line with the general official approach that culture was a racially exclusive realm. The imagery of Haw Par Villa as a Chinese organism in its death throes on account of Western supplements which had turned out to be alien, incompatible and poisonous was consistent with the other contention in the Chinese press that even Chinese Singaporeans represented in the Englishlanguage press had an inadequate appreciation of Chinese culture and hence of Haw Par Villa. This ethno-centric mindset precluded their appreciation of contributions from Chinese Singaporeans operating in the English language which had critiqued the Villa's position from premises transcending ethnic concerns and in relation to the larger issues of state governance and humanity.

${ }^{88}$ Ibid., 21 May 2000. 
One such position had been articulated by prominent and vocal veteran architect Tay Kheng Soon. He was among those featured in the Straits Times straw poll. His stand was unequivocal and characteristically blunt: 'Tear it down. It is so old and out-of-date. Singaporeans don't have any sentiments left for it. I went there once as a child and I have no intention of ever going back there again' ${ }^{89} \mathrm{He}$ was duly taken to task in the Chinese press for what it condemned as a highly arbitrary verdict. However, Tay's dismissal of the relevance of Haw Par Villa was not likely to be that of a calculating pragmatist. In fact, he has been a long-time critic of the state's utilization of public space in Singapore, particularly the public housing and urban renewal programmes. More fundamentally, he was highly critical of what he considered as the conformity of thought, lack of creativity and culture of obedience that the Singapore nanny state had engendered in achieving rapid modernization, at the expense of what he called 'modernity'-'autonomy of reason, autonomy of aesthetics, autonomy of morality'. The result, he argued provocatively, was that the younger generation of Singaporeans were 'fluffy dough', without courage and character. ${ }^{90}$ Following his line of argument, Haw Par Villa would be an anathema: chauvinistic, oppressive and downright hypocritical. It was overseas Chinese rather than Singaporean. The morals and virtues that it ostensibly taught lauded behaviour that was submissive, particularly on the part of women and the young. Worst of all, the Villa had instilled in the young a fear of retribution for transgressions as found in the Ten Courts of Hell rather than aiming to inculcate reasoning and civic consciousness. The Chinese-language defenders of Haw Par Villa precluded the possibility of such a humanist reading, preferring to see its detractors only as people who were deficient in their appreciation of Chinese culture.

Another contribution to the meaning of Haw Par Villa to Singapore that transcended the ethnicized framework was enunciated by Singapore's most widely published English-language novelist and short story writer Catherine Lim, who used it as an imagery of potentially liberating ambiguities and possibilities. In 1994, Lim wrote a couple of opinion pieces in The Straits Times calling for the prime minister Goh Chok Tong to put into practice the policy of a more open and

${ }^{89}$ The Straits Times, 5 May 2000.

${ }^{90}$ Interview, "Tay Kheng Soon and "SPURS": Activism in the early days of Singapore's history' (1999), SINTERCOM: Singapore Internet Community, www.newsintercom.org 
consultative government that he had talked about and to break away from the sterner ways of his predecessor Lee Kuan Yew. Such open criticism of the political leadership by a member of the public was unprecedented, and Lim was sternly warned that she had gone 'beyond the pale'. She was also told that should she wish to engage in politics she should join a political party. ${ }^{91}$ Lee Kuan Yew later referred to the significance of the incident:

Supposing Catherine Lim was writing about me and not the prime minister... She would not dare, right? Because my posture, my response has been such that nobody doubts that if you take me on, I will put on knuckledusters and catch you in a cul-de-sac.... Anybody who decides to take me on needs to put on knuckle-dusters. If you think you can hurt me more than I can hurt you, try. There is no other way you can govern a Chinese society. ${ }^{92}$

The incident made Lim a 'cause célèbre of the chattering classes' even though she did not prolong the public debate with the government at that point in time. ${ }^{93}$ She continued with her stories on Singapore life, especially Chinese women, their personal and family relationships, and the cross-currents of their cultural moorings. In her 2001 novel, Following the Wrong God Home, however, she dwelt imaginatively on the issues that had been present in the fracas. 'In modern-day Singapore, a young woman is about to break all the rules', states her publisher on the back cover of the book. The first momentous step in this process takes place in Haw Par Villa (Sai Haw Villa in the novel). The protagonist Yin Ling, a gifted and sensitive convent-schooled graduate student in linguistics, is married to a wealthy, high-achieving economist with a civil service appointment that promises to lead to a bright political career. He is generous with financial support for her family, including the elderly former family servant, but demands that she fits into his image of the perfect wife, 'claiming entitlement to her body, mind and

${ }^{91}$ Cherian George, Singapore the air-conditioned nation: Essays on the politics of comfort and control (Singapore: Landmark Books, 2000), pp. 41-2.

${ }^{92}$ Han Fook Kwang et.al., Lee Kuan Yew: The man and his ideas (Singapore: Straits Times Press, 1998), p. 126.

${ }_{93}$ Cherian George, Singapore the air-conditioned nation, p. 42. Eleven years later, at the next changeover of Prime Ministership from Goh Chok Tong to Lee Hsien Loong, the son of Lee Kuan Yew, she contributed a follow-up provocative commentary on 'A new model PAP governance: Utopia or dystopia?' to The Straits Times, 10 May 2005, arguing that 'a nation of politically naïve citizens can threaten Singapore's survival' and ironically 'it is time the Government teaches politics and independent thinking to its people'. 
soul'. ${ }^{94}$ When they are engaged, however, Yin Ling 'falls clandestinely in love' with an outspoken American, Ben Gallagher, one of the many expatriate lecturers whom the local university had begun to recruit. The 'Founder of Modern Singapore' recognized that their expertise was needed, but that they should keep out of local politics, 'so he stretched out one hand in welcome and clenched the other to show the famously ruthless knuckles at the ready'. ${ }^{95}$ Ben appreciates 'the depth of her inner life' as no one does, and challenges Yin Ling to be true to it. He also impetuously defies the rules of living the good life in Singapore. He berates his students: 'Think, for God's sake .... Think. Speak up. Ask questions. Challenge me'. ${ }^{96}$

Yin Ling and Ben Gallagher establish Haw Par Villa as their point of rendezvous. She is there to help her elderly former family servant to find a final home for the latter's most treasured figurine of a modest, unknown deity, and is thus ostensibly in consonant with the moral structure of the Villa. But the Villa also provides a refuge for their clandestine trysts: 'in the tantalising semi-darkness of the Courts of Hell, where a man and a woman could stand close together, could turn to face each other for a kiss, without attracting the attention of other visitors $\ldots{ }^{97}$ Its gruesome scenes of punishment are the only displays in the Villa not in the open air and bright sunshine, so as to highlight the burning coals and dancing flames of hell. The embellishment by appropriate sound effects is meant to be cautionary tales against immoral behaviour, but ironically make it perfect for the privacy they seek. To them, their secret liaison defies only social conventions. In the Chinese theme park, they are mistaken for a local female-Western male couple visiting a tourist spot, with the presence of an elderly woman lending respectability to their intimacy. Within the three months left before Yin Ling's wedding, they plan to visit all the Ten Courts, one each visit, and once there, they are to 'drop everything' ${ }^{98}$ : her impending marriage to a man who relishes the great Singapore bargain; 'the tallest buildings, cleanest roads, sleekest condominiums, fattest bank accounts ... [for] your soul, your dreams, and your fight'; ${ }^{99}$ and her lover's reputation as a white expatriate lecturer with a messy

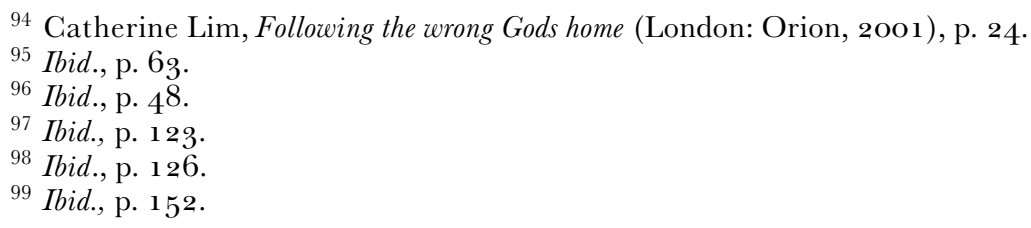


divorce settlement and a string of female admirers in the university. In the novel's denouement, brought on by the 'heavy knuckles' that descend on Gallagher, Yin Ling leaves her husband and even her young son in pursuit of her freedom and self-discovery. Before setting off to America, she fulfils the now deceased servant's wish, and journeys to return the old god to his home village in China. On the return flight, she perishes in an air crash.

In killing off her protagonist, Catherine Lim reaffirms the 'sheer survival on a cold, hard planet-and a colder, harder bit of that planet called Singapore'. ${ }^{100}$ For the country to continue on its chosen path, it has to be purged of Yin Ling and her defiance against the clearly demarcated categories and hard-headed rules of surviving in Singapore. She finds temporary respite in the accommodating and flexible space in Haw Par Villa, where wrathful gods and compassionate ones co-exist. It is replete with deities, but is not a place of worship where the faithful enact a fixed set of rituals. Tourists, local visitors, and devotees share the space, and among the latter, there are those who offer the gods garlands of jasmine, dahlias and marigold rather than the Chinese joss-sticks and sumptuous food 'the worshipper might have come after doing a similar obeisance at a Hindu shrine then perhaps proceeded to a Christian church with a third garland, playing safe in this multi-religious society'. ${ }^{101}$ Lim's Haw Par Villa is both carnal and spiritual; the repository of tradition and a refuge from conventions; and a local space where a Westerner can still remain part of the scene. This notion of a broad, flexible and inclusive multiculturalism which permits blending and overlapping is contrary to the official strictures that demarcate and patrol borders, and stress difference and exclusion. However, Haw Par Villa can be only a temporary escape for Yin Ling, a mirage of liberating indeterminacy. In the end, the choices are still defined in clear-cut terms: 'East or West; duty or passion; reality or dream' (back cover). Haw Par Villa, complicit in its protagonist's spiritual release, cannot be allowed to survive either. In the novel, Catherine Lim has the Villa torn down and replaced by 'a huge condominium development called Paradiso 1 right up to Paradiso 5 ${ }^{102}$ A modular paradise emerges out of the ruins of one which had been shaped organically.

${ }^{100}$ Ibid., p. 134.
101 Ibid., p. 121.
102 Ibid., p. 370. 


\section{Haw Par Villa reloaded: Redefining Singapore's national identity}

Unlike its fate in Catherine Lim's novel, the Singapore Haw Par Villa continues to stand. Making virtue out of necessity, the same Tourism Board officials behind the Dragon World theme park concept, unable to interest any world-class operators, announced that 'Haw Par Villa will not compete with bigger, grander, modern attractions. Our intention is to progressively and organically bring the park back to what it was [-] a philanthropist's private garden made interesting by thousands of Chinese mythological statues and figurines that immortalise moral values and Chinese cultural heritage'. ${ }^{103}$ The strategy would be to 'preserve what we have and slowly upgrade the facilities for the comfort of visitors' ${ }^{104}$ such as providing 'world-class toilets'. ${ }^{105}$ A tender was called for a project consultant to 'consolidate' Haw Par Villa by reconfiguring it to the original, smaller Tiger Balm Gardens and removing almost all traces of the theme park fixtures. Entry to the grounds would be free-of-charge, ostensibly in response to a Forbes research survey commissioned by the Tourism Board in September 2000, which had found that 85 percent of the 6 oo people polled had considered it to be part of Singapore's heritage. ${ }^{106}$ The Villa was then designated by the National Heritage Board as a historical site in April 2003. ${ }^{107}$ The Tourism Board now professed that it did not want to commercialize the Villa nor rely on high-tech gimmicks, but rather let the exhibits 'tell their own stories'. ${ }^{108}$

Nevertheless, old habits die hard and the Board maintained its grip on providing the framework within which these stories were to be understood. With the Chinese Heritage Centre serving initially as a consultant, it has appended an overseas Chinese museum to the Villa to 'connect with the Chinese diaspora' and to tell 'the saga of the 35 million overseas Chinese'. Named Hua Song ('In praise of the Chinese community') and which will open sometime in 2006, the museum's anchor exhibition gallery Hall of Myriad Strands is to feature a social history of Chinese migration and settlement. It will narrate how the new arrivals 'adapted to the hostile environment of

\footnotetext{
103 The Straits Times, 22 Jan. 2004.

${ }^{104}$ Ibid., 3 Apr. 2001.

105 Ibid., 2 Nov. 2001

${ }^{106}$ Ibid., 14 Dec. 2000.

${ }^{107}$ Ibid., 15 May 2004.

${ }^{108}$ Lianhe zaobao, 18 Jan. 2004.
} 
the host country, some struggling to eke out a living while others seized opportunities to carve out business niches for themselves' ${ }^{109}$ Visitors are meant to 'soak in the spirit of adventure and enterprise of the early Chinese migrants who seized opportunities amidst adversity to make good in their adopted land'. ${ }^{110} \mathrm{~A}$ retired senior director of the Board who had been involved with Haw Par Villa since its acquisition by the state serves as the museum's project director and curator. ${ }^{111}$ Overseas Chinese communities worldwide are being contacted for donations of memorabilia. They are informed that the 'world-class attraction by virtue of the high historical value of its exhibits' will 'tell your story and that of your overseas Chinese ancestors ... for people all over the world to understand the influence of the Chinese diaspora on modern society and to understand how one ethnic community can become so successful internationally' ${ }^{112}$ Overall, the museum's theme is the overseas Chinese's significant contribution to the economies of their host countries. It noted that 'what makes the [Chinese migration] story remarkable is the role that Chinese miners, plantation workers and entrepreneurs played in the economic development of Southeast Asia and the Americas.... Hua Song highlights this history most effectively'. ${ }^{13}$ This is in contrast to the stereotype long propagated by Southeast Asian nationalist and post-colonial political leaderships

${ }^{109}$ Hua Song Museum newsletter, not dated.

110 Ibid.

111 Pamelia Lee, the author of the modestly titled, self-published Singapore, tourism and me (Singapore: Pamelia Lee Pte Ltd., 2004) and who was involved in the process of the Singapore Tourist Promotion Board's taking over of Haw Par Villa and the planning of its transformation into the Dragon World, has claimed in her autobiography that when she visited the redeveloped park on its opening day she was 'personally disappointed. The films were superficial and huge sums of money were spent on fancy mechanisms, like animatronics. The worst part was that they used Western eyes to tell Chinese stories', p. 167. Her retrospective critique must constitute an object lesson to the investors who had won the tender to develop the park according to the Board's vision. Lee's earlier publication venture was the editing of a cookbook by the mother of her husband, who is the youngest brother of Lee Kuan Yew. The Straits Times, 16 Apr. 2004.

112 The Straits Times, 15 May 2004.

${ }^{113}$ Foreword by Wang Gungwu, in Suchen Christine Lim, Stories of the Chinese Overseas (Singapore: SNP International, 2005), p. 10. The book, commissioned by the Hua Song Museum and the Singapore Tourist Board, is the story of migrant workers and sojourners who are 'our great-grandfathers and uncles, and our greatgrandmothers and aunts'. (p. 13) It is a 'jewel box of images' (back cover), with brief text accompanying the photographs and is organized according to geographical regions and nation states. 
that they were economic animals who held no loyalty to the indigenous societies.

This paradigm shift in Singapore has been driven by developments in the region. With the rapid opening up of China's economy and tourism market, Singapore's attempt to be a miniature essence of China with the Dragon World and Tang Dynasty Village projects had become increasingly outmoded. In the branding exercise that the Singapore Tourism Board undertook in 1996, the slogan adopted was 'New Asia' Singapore, but by the turn of the millennium, many other regional destinations were also calling themselves New Asia, to the point that when people said 'New Asia', they thought of Shanghai. ${ }^{114}$ 'Uniquely Singapore' was thus adopted as the new tourism tagline in 2004. ${ }^{115}$ The new strategy included differentiating Singapore from mainland China, and building on an overseas Chinese heritage. Indeed, the Tourism Board launched advertising campaigns along such lines in prospering provincial Chinese cities and the number of flights between Singapore and China were increased, fuelling the rise in mainland tourist arrivals. ${ }^{116}$

The same impulses, relating to the mythologization of the Chinese migrants and to the strengthening of ongoing Chinese diasporic economic networks, lay behind the setting up of the Chinese Heritage Centre (Huayi guan, literally as Association for Chinese Descendants) in 1995. The Centre is located in a landmark building inherited from the former Nanyang University, the only Chinese-language medium university in Southeast Asia from the mid-1950s to 1980. It received 5 million dollars of funding from the Singapore government, as well as 1 million each from Singapore banker and community leader Wee Cho Yaw, and Indonesia's billionaire Liem Sioe Liong. ${ }^{117}$ Lynn Pan, author of Sons of the Yellow Emperor, was appointed as its first director, and her almost exclusive task was to produce an encyclopaedia of

114 Malaysia dealt the Singapore 'New Asia' tagline a mortal blow when it came up with the slogan 'Malaysia Asia', selecting Penang-born actress Michele Yeoh as its tourism ambassador. Yeoh was the star of both the James Bond movie Tomorrow Never Dies (1997) as well as the internationally acclaimed Lee Ang kungfu movie Wohu canglong (Crouching Tiger, Hidden Dragon) (2000). Yeoh, an accomplished martial arts exponent, does not use doubles for her stunts, and is thus respected in both the Western and Asian film circles. Singapore, for all its vaunted emphasis on its Chinese population being bi-cultural, has yet to produce an international popular culture personality of Yeoh's calibre. The Straits Times, 10 Mar. 2004.

${ }^{115}$ Ibid., 10 Mar 2004.

${ }^{116}$ Ibid., 31 May 2004.

117 Ibid., 13 Dec. 1995 . 
overseas Chinese. ${ }^{118}$ The Centre comprises a team of researchers and a specialist library devoted to studying the Chinese diaspora, and has since mounted occasional exhibitions, besides publishing the Journal of Chinese Overseas. ${ }^{119}$ The Chinese Heritage Centre has marked a shift in Singapore's identification of its Chineseness with the overseas Chinese rather than through the classical texts examined by the Institute of East Asian Philosophies set up in the 1980s. It is therefore not only a companion to the refashioned Villa, with its appended Hua Song Museum, but also a forerunner in signalling the forging of a new nexus between Singapore's nationhood and the Chinese diasporic culture.

Understood in this light, the Sun Yat Sen Nanyang Memorial Hall can similarly be regarded as another counterpart to the Haw Par Villa of 2005. The Hall was opened in 2001 after a 7.5 million dollars extensive renovation to the mansion that Sun Yat Sen had stayed in on a few occasions when he had been in Singapore between 1906 and 1909. The focus of the exhibits is on Sun's relations with the building and with Singapore, as well as his revolutionary activities among overseas Chinese communities in various parts of Southeast Asia. ${ }^{120}$ Singapore Chinese have been urged to 'take great pride' in this Memorial Hall as it is a 'testament to the historical contributions our forefathers made to the important 1911 revolution, not only with money but also with their blood and their lives'. ${ }^{121}$ Viewing the 1911 revolution as being larger in scope and scale than the American, French or even the Bolshevik revolutions, the authorities postulated that the Singapore Chinese's forefathers had contributed towards a monumental event which 'changed the way Chinese all over the world saw themselves' and 'altered the course of history'. ${ }^{122}$

118 Although Lynn Pan left the Centre soon after completing the editing of The Encyclopedia of the Chinese Overseas (Singapore: Archipelago Press and Landmark Books, 1998), she was nonetheless commissioned to come back and craft the first draft of the story line for the proposed Hua Song Museum. Her recommended plot revolves around four main themes: Leaving home, making good, family and habitat, and crossing boundaries. Lianhe zaobao, 27 Mar. 2002; communication with Lily Tan of the Heritage Services Division, National Heritage Board, Jul. 2002. Pan's proposed story line has been substantially altered as the Hua Song Museum project passed through various hands.

${ }^{119}$ Website of the Centre, www.chineseheritagecentre.org. The inaugural issue of the Journal of Chinese Overseas has appeared in May 2005.

${ }^{120}$ Huang Jianli and Hong Lysa, "History and the imaginaries of "Big Singapore": Positioning the Sun Yat Sen Nanyang Memorial Hall', Journal of Southeast Asian Studies, 35.1 (Feb. 2004): $65-89$.

121 The Straits Times, 26 Mar. 2000.

122 Ibid., 30 Apr. 2001. 
The Memorial Hall has been decreed 'a cultural shrine for all ethnic Chinese Singaporeans', commemorating the vital contributions of overseas Chinese to the epochal Chinese Revolution of 1911, and in turn to world history. ${ }^{123}$

A significant triumvirate has therefore emerged in the cultural landscape of Singapore within the last decade. The Haw Par Villa (-Hua Song Museum), the Chinese Heritage Centre and the Sun Yat Sen Nanyang Memorial Hall together boldly posit that the modernizing dynamism of the Chinese today resides in the overseas Chinese, and particularly in Singapore where overseas Chinese the world over can find a narrative of their history. Through this process, Aw Boon Haw has in fact achieved his ambition posthumously, for it is in his Villa that 'Hua Song' is located, mythologizing him as the ancestor of the diligent, intelligent and resilient ideal 'New Asia' Singaporean entrepreneur. His Haw Par Villa has been made emblematic of an essentialist Chinese virtue of 'paying back to society after one has benefited from it', even while this approach has to entail the suppression of the historical conditions underlying the form and significance of such philanthropy. The wilful diasporic horizons of Aw Boon Haw and his cohort, including the traits of opportunism, self-promotion and even ruthlessness that were an inextricable part of their success, have been dehistoricized, and thus diminished and tamed to adhere to virtuous national dimensions.

123 Speech by the Minister of Information and the Arts George Yeo on 12 Nov. 1996, Press Release 33 Nov/ogB-1/o6/1 1/12; The Straits Times, 13 and 15 Nov. 1996. 